\begin{tabular}{llll} 
MANAS Sosyal Araştırmalar Dergisi & $2019 \quad 2019$ & Cilt: 8 & Ek Sayı: 1 \\
\hline MANAS Journal of Social Studies & S: 1 & 201
\end{tabular}

\author{
Atıfta Bulunmak İçin / Cite This Paper: Mutlu, B. (2019). "John M. Coetzee'nin Gözüyle Filozoflar \\ ve Hayvanlar", Manas Sosyal Araştırmalar Dergisi, 8(Ek Sayı 1): 725-743
}

Geliș Tarihi / Received Date: 19.11.2018

Kabul Tarihi / Accepted Date: 12.12.2018

Araştırma Makalesi

\title{
JOHN M. COETZEE’NIN GÖZÜYLE FÍLOZOFLAR VE HAYVANLAR
}

\author{
Dr. Öğr. Üyesi Barış MUTLU \\ Van Yüzüncü Y1l Üniversitesi, Güzel Sanatlar Fakültesi, Sahne Sanatları Bölümü \\ barismutlu.79@yahoo.com \\ ORCID ID: 0000-0001-6807-6448
}

\section{$\ddot{O} \mathbf{z}$}

Güney-Afrikalı Coetzee'yi, Iris Murdoch gibi daha çok edebiyatçı yönüyle biliriz. Kendisinin edebiyat literatüründe yeri 2003 'te Nobel Ödülü’ne layık görülecek denli etkili ve önemlidir. Romanlarını İngilizce yazan bu önemli edebiyatçının birçok romanı da Türkçe'ye çevrilmiştir. Ancak Coetzee'nin edebiyat dışında önemli bir felsefe tartışma alanı olan hayvanlara yönelik bir ilgisi de mevcuttur. Bu konuda üniversitede dersler vermiş ve bu dersleri de The Lives of Animals adı altında yayımlanmıştır. Coetzee romanları ve bu son eseriyle önemli filozofları etkilemeyi başarabilmiştir. Örneğin Peter Singer, Cora Diamond, Stanley Cavell, John McDowell, Stephan Mulhall gibi önemli filozoflar bir şekilde Coetzee'nin eserlerine yönelmişlerdir. Çağdaş hayvan hakları tartışmalarının öncüsü Singer, The Lives of Animals'a görüşleriyle katkı sağlamıştır. Son dönemlerde edebiyat ve sinema felsefesi üzerine olan eserleriyle dikkat çeken Mulhall ise doğrudan Coetzee üzerine bir eser kaleme almıştır. The Wounded Animal adını taşıyan bu eser, Coetzee'nin edebiyatçı yönüne dikkatle onun felsefe ve hayvanları ele alışını inceler. Bu çalışmamızdaki amacımız ise Coetzee'nin hayvanlarla ilgili açıklamalarını görmektir; bir edebiyatçının, özellikle felsefe içerisinde önemli bir tartışma konusu olan hayvanlara yönelik tespitlerini değerlendirmektir.

Anahtar Kelimeler: Coetzee, Hayvanlar, Felsefe, Edebiyat, Şiir.

\section{PHILOSOPHERS AND ANIMALS FROM THE PERSPECTIVE OF JOHN M. COETZEE}

\begin{abstract}
We know the South-African Coetzee more as a man of letters as Iris Murdoch. His place in literature is as important as he was awarded to Nobel Prize 2003. Many novels of this important writer which were written in English were translated into Turkish. Coetzee, however, has an interest in animals besides literature which is an important field of philosophical discussions. He has lectured at the university on this subject and they have been published under the name of The Lives of Animals. Coetzee has succeeded in influencing important philosophers with his novels and this latest work. For example, important philosophers such as Peter Singer, Cora Diamond, Stanley Cavell, John McDowell, and Stephan Mulhall have somehow turned to Coetzee's works. Singer, a pioneer of contemporary animal rights discussions, contributed his views to The Lives of Animals. Mulhall, who recently drew attention with his works on philosophy of literature and cinema, wrote a book directly on Coetzee. This work, titled as The Wounded Animal, examines Coetzee's approach to philosophy and animals by paying attention to his literature. The purpose of this study is to see Coetzee's arguments on animals; to evaluate the assesses of a literary man for animals which is an important subject of discussion especially within philosophy.
\end{abstract}

Keywords: Coetzee, Animals, Philosophy, Literature, Poetry. 


\section{GİRIŞ}

Güney Afrikalı John M. Coetzee'nin etkileyici edebiyat eserleri ile birlikte yayımlanan diğer önemli eseri The Lives of Animals'tır. Bu eser üniversitede verdiği iki dersten (lecture) oluşmaktadır. Coetzee bu derslerini "The Philosophers and the Animals" ve "The Poets and the Animals" adı altında iki alt bölümde sunmuştur. Eserin ilk ana bölümünü bu iki alt bölüm oluştururken diğer bölümde ise derslere yönelik farklı disiplinlerden dört önemli ismin öz düşünceleri (reflections) yer alır. Bu önemli isimler, edebiyat kuramcısı Marjorie Garber, hayvanlar konusunda öncü ve eşsiz eserleri olan filozof Peter Singer, din uzmanı Wendy Doniger ve primatolog Barbara Smuts'tur. Derslere yönelik bu isimlerin değerlendirmeleri kesinlikle anlamlı ve önemlidir. Çünkü dersler edebi bir kurgu ile ilerler ve bu kurgu içerisinde de felsefi, dinsel ve hayvanların doğasına yönelik ilginç tespitler yer alır. Örneğin kavramlara, akıl yürütmeye odaklanan filozofların hayvanlarla ilgili açıklamaları yeterli bulunmaz. Kant gibi önemli bir filozofun hayvanlar konusunda pek bir şey söylememiş olmasına dikkat çekilir. $\mathrm{Bu}$ çalışmamızda Coetzee'nin hayvanlar konusunda ses getiren eseri üzerinde duracağız. Eserin gidişatına uygun iki alt başlıkta ilerleyeceğiz; öncelikli olarak Coetzee'nin ilk dersini daha sonra ise ikinci dersini göreceğiz ve sonuç kısmında ise bu derslerin amacına dair bir değerlendirme yapacağız.

\section{FILOZOFLAR VE HAYVANLAR}

The Lives of Animals etkileyici bir edebi kurguyla ilerler. Başkahramanımız Avusturyalı bir edebiyatçı olan ve özellikle The House on Eccles Street (1969) romanı ile bilinen Elizabeth Costello'dur. Bu kurguda Costello istediği bir konuda ders vermek üzere Appleton College'a davet edilmiştir. Daveti yapan ilgili üniversitenin İngiliz Edebiyatı Bölümü’dür. Söz konusu üniversitede ayrıca Costello'nun John Bernard adındaki akademisyen oğlu çalışmaktadır. Costello oğlu John'u iki yıldan beri görmemiştir. John uçakla gelecek olan annesini karşılamak için eşi Norma ve çocukları ile havaalanına gider. Annesini gören John, iki yıldan beri görmediği ve kendilerinde üç gün kalacak olan annesinin ne denli yaşlandığını fark ettiğinde epey bir şaşırır; annesinin griye çalan saçları tamamen beyazlaşmış, omuzları çökmüş ve etleri de sarkmıştır. Birbirlerini gören anne ve oğul selamlaşır. İkisi de sessiz bir şekilde kalabalığı takip ederlerken oğlu annesine uzun bir yolculuk yaptığını, dolayısıyla yorulmuş olması gerektiğini söyler. Annesi oğluna hak verir; uyumaya hazır olduğunu, uçakta sadece çok kısa bir süreliğine uyuyabildiğini belirtir. Daha sonra Costello dışarıda bekleyen gelini Norma ve çocuklarını görür ve Norma'yla kucaklaşır. Ancak bu kucaklaşmada anlatıcı oğlu John'un ağzından, annesi Costello'nun ve eşi Norma’nın arasının pekiyi olmadığı (Coetzee, 1999: 15-16), aslında her ikisinin de birbirlerini hiç 
sevmediği bilgisini verir (Coetzee, 1999: 17). Bu yüzden John annesinin bir otelde kalmasının daha bile iyi olabileceğini aklından geçirir. Öte yandan John annesine bu öneriyi yapamayacağını, kendinde bu gücü bulamayacağını görür (Coetzee, 1999: 15). Ancak annesi bu öneriyi yapsa hatta bu öneriyi salt formaliteden dile getirmiş olsa, “tamam, olur” diyeceğine pek de kuşkusu yoktur.

$\mathrm{Bu}$ şekilde gerçekleşen buluşma sonrasında Costello oğlunun evine ulaşır. Norma kayınvalidesi için hafif bir akşam yemeği hazırlamıştır. Ancak sofrada üç tabak vardır; Costello, kocası ve kendisi için. Bunun üzerine Costello torunlarının yemek yiyip yemeyeceklerini sorar. Norma çocukların oyun odasında yiyecekleri cevabını verir. Costello nedenini aslında bilse de gelinine iki kez "Neden?" diye sormak zorunda hisseder. Norma kayınvalidesine kızgın bir bakış atar. Costello’ya cevabı oğlu vermek zorunda kalır: “Anne... çocuklar akşam yemeği için tavuk yiyecekler, tek sebep bu.” (Coetzee, 1999: 16). Costello ise sadece "anliyorum" der. Bu kısa diyalogdan hemen önce hikayede anlatıcı, Costello'nun masada et görmeyi sevmediğini, Norma'nın kayınvalidesinin ince hassasiyetlerine rağmen çocukların yemeğini değiştirmeyi istemediğini belirtir (Coetzee, 1999: 16). Yani iki kadının aralarının gerçekten iyi olmadığını görmeye devam ederiz; çünkü Norma sadece üç gün kalacak Costello için bunu yapmayı reddetmektedir. Costello ziyaretinin daha ilk gününde torunlarıyla ayrı masalarda yemek zorunda kalır. Oğlu John'un ise bu durum karşısında bir şey yapmadığını, bir şey söylemediğini görürüz. Kendisi muhtemelen bu gibi olaylarla karşılaşacağını bildiği için annesinin otelde kalması olasılığını düşünebilmiştir. Aslında hikayenin hemen başında anne ve oğlun arasının da pek de iyi olmadığını düşünebileceğimiz şu cümlelerle karşılaşırız:

John Bernard dünyada kendi tarzını yaratmayı tercih ettiği için Elizabeth Costello ile ilişkisini yayıp saçmadı (broadcast). O, kız kardeşi ve ölmüş babasının onun [annesinin] romanlarında ara sıra acı verici bulacağı bir şekilde kaleme alındığı gerçeğine rağmen annesinden utanmıyor aksine gurur duyuyordu. Gelgelelim hayvan hakları konusunda bir kez daha onu işitmek istediğinden emin değildi, özellikle hemen sonrasında yatakta eşinin rahatsız edici yorumlarıyla karşılaşacağını biliyordu... Norma ve annesi birbirlerini hiçbir zaman sevmediler. Belki de annesi oğlunun evlendiği herhangi bir kadını sevmemeyi seçecekti (Coetzee, 1999: 16-17).

İlginç olan ise üniversitedeki hiç kimse Costello'nun, üniversitede Fizik ve Astronomi alanında asistan profesör olan oğlu olduğunu bilmemektedir.

Hikayede John'nun eşi Norma ile John Hopkins Üniversitesi'nde lisans öğrencisi iken tanıştıklarını ve sonrasında da evlendiklerini öğreniriz. Bu evlilikte ironik olan ise Norma'nın zihin felsefesi üzerine doktorasını almış bir felsefeci olmasıdır. Zihin felsefesi üzerine 
uzmanlaşmış olan Norma, eşi ile birlikte geldiği Appleton'da kocası gibi bir üniversite hocalığı kadrosu bulamamıştır. Hatta hikayenin belirttiğine göre bu durum iki eşin birbirleriyle çatışmalarına da yol açmaktadır (Coetzee, 1999: 17). Norma böyle bir gergin ruh hali içerisinde "bir felsefe dergisi için primatlarda dil öğrenimi deneyleri üzerine bir inceleme makalesi yazmaktadır" (Coetzee, 1999: 17). Dahası John için, böyle bir ortamda eşinin ilgili makale içerisindeki bir dipnotta annesini dışlayıcı, saygısız bir şekilde ele alması pek de şaşırtıcı olmayacaktır. $\mathrm{Bu}$ ilişkiler çerçevesine eklemememiz gereken bir diğer nokta ise John'un hayvanlarla pek bir bağının olmaması, sadece çocukken kısa süreliğine hamster bakmış olmasıdır. Hikayeden öğrendiğimiz önemli bir konu da John ve karısı Norma'nın büyük çocuklarının bir yavru köpek istemesine direnmeleridir, köpekle ilgili düşündükleri tek şey köpeğin cinsel ihtiyaçları tarzında ortaya çıkaracağı kimi sorunlardır (Coetzee, 1999: 17). O halde karşımızda et yemeyen, önemli ve tanınmış bir edebiyatçı olan Costello, Fizik ve Astronomi alanında Asistan Profesör olan oğlu John ve zihin felsefesi üzerine doktorasını almış bir felsefeci olarak gelini Norma vardır. Oğlu ve gelininin hayvanlarla araları iyi değildir ve oğullarının bir yavru köpek sahibi olma isteği karşısında duyarlı değildirler. Costello oğlunun çalıştığı üniversiteye ders vermek için gelmiş ve bu süre içerisinde oğlunun yanında kalacaktır.

Yukarıdaki hikaye özetinden merak edip bilmek istediğimiz kimi şeyler olabilir. Örneğin Costello'nun oğlunun hayvanlarla ilişkisinin nasıl olup da iyi olmadığını merak edebiliriz. Acaba annesi oğluyla yeterince ilgilenmedi mi? Costello o zamanlar et yiyordu ve evde hayvanları yoktu da bu yüzden mi oğlu hayvanlarla yakın bir ilişkiye sahip değildi? diye kendimize sorabiliriz. Ya da Costello oğlunu özgür bırakıp onun kısa süreliğine bir hamstera sahip olma isteğine saygı gösterdi diye de düşünebiliriz. Coetzee'nin hikayede bu konuda bir şey söylemediğini belirtelim. Ancak hayvanlarla büyüyen ve yaşayan biri olarak şöyle bir yaşanmışlığın olabileceğini kurgulayabiliriz: Costello o zamanlar belki de kocasından dolayı hayvan bakmıyordu, kendisi hayvan sevse ve hayvanlarla büyüyen biri olsa bile kocasının göstermiş olduğu hassasiyeti kabullendi. Bu durumda belki de kendisi kocasını, oğlunun sadece hamster bakabilmesi için ikna edebildi. Ve bu süreç de bildiğimiz kadarıyla uzun sürmedi.

$\mathrm{Bu}$ varsayımımızla birlikte tekrardan hikayeye döndüğümüzde, John'un dersten sonra öğle yemeği için eve geldiğini sonrasında ise annesini arabası ile şehirde dolaştırdığını görürüz. Costello'nun dersi öğleden sonra başlayacaktır, dolayısıyla ders öncesinde bu gezi için zaman bulabilmişlerdir (Coetzee, 1999: 17). Gezi sonrasında Costello oğluyla ders vereceği yere gelir. Dersin tanıtımını İngiliz Bölümü hocalarından, Costello üzerine çalışmaları olan Elaine Marx yapar. Costello bu tanıtımdan sonra dersine başlar. Kendisi öncelikli olarak Amerika Birleşik Devletleri'ne iki yıldan beri gelmediğini, en son yine bir ders vermek için geldiğini ve bu 
dersini de büyük edebiyatçı Kafka ve onun özellikle “Akademi İçin Bir Rapor” başlıklı hikayesi üzerine verdiğini hatırlatarak (Coetzee, 1999: 18) şunları söyler:

O zaman verdiğim derste olağanüstü Franz Kafka’ya, özellikle yaşamının hikayesinicanavardan (beast) insan olmaya yaklaşan bir şeye yükselişini- öğrenmiş (learned) bir toplumun üyeleri önünde duran eğitimli bir maymun (ape) olan Kırmızı Peter hakkındaki “Akademi İçin Bir Rapor”a gönderimde bulunacak sebebim vardı. O zaman kendimi biraz Kırmızı Peter gibi hissetmiş ve bunu da söylemiştim. Bugün bu his, size çok daha açık geleceğini ümit ettiğimiz sebeplerden dolayı daha da güçlüdür (Coetzee, 1999: 18).

Dersler sıklıkla amacı seyircileri rahatlatmak olan endişesiz ifadelerle başlar. Kendim ve Kafka'nın maymunu arasında resmettiğim karşılaştırma bu şekilde endişesiz bir ifade olarak alınabilir, sizi rahatlatmak anlamına gelebilir, bir tanrı ya da bir canavar olmayıp sadece sıradan bir insan olduğumu söylemek anlamına gelebilir... İşin başında belirtmek isterim, bu sözüm/işaretim Kırmızı Peter ile ilgili hissettiğim sözün nasıl niyetlenildiği ile ilgili değildi. $\mathrm{Bu}$ sözü ironik olarak niyet etmedim. Söylediğim şeyi kastediyor. Kastettiğim şeyi söylüyorum. Yaşı bir kadınım. Kastetmediğim şeyleri söyleyecek kadar artık zamanım yok (Coetzee, 1999: 18).

Costello bizler için hala kapalı olan, nereye gideceğini tam kestiremediğimiz bu çarpıcı sözlerini derslerinin de konusu olan hayvanların korkuları ve ölümleriyle ilişkilendirmek için kullanır. Belirttiği gibi hayvanlar dünyanın her yerindeki üretim çiftliklerinde, kesimhanelerde, laboratuvarlarda türlü korkularla ve ölümlerle yüzleşmektedirler (Coetzee, 1999: 19). Ayrıca hayvanlara şiddeti merkeze alan birçok eğlencemizin olduğunu da unutmayalım. Bu gibi olgular hayvanların korkularını ve ölümlerini çok sıradan bir şekilde ele aldığımızı göstermektedir. Costello hayvanların yaşadığı korku ve ölüm deneyimlerini, Hitler Almanya'sında kamplarda tutulan ve daha sonrasında birçoğu yakılıp öldürülen Yahudiler'in deneyimlerine benzetir. Çünkü bu insanlar da Nazi kasapları tarafından hayvanlar gibi öldürülmüş ve boğazlanmıştır (Coetzee, 1999: 19-20).

Costello kurduğu ve tekrardan ele alacağı bu tartışmalı benzerlikte öncelikli olarak Kafka'nın raporuna uzanacağı bir şekilde “akıl” üzerinde durur. Dikkat çektiği gibi birçok fillozof, aklın insan yaşamındaki gücüne dikkatle insanları hayvanlar karşısında daha değerli görebilmiştir. Örneğin Thomas Aquinas sadece insanın Tanrı imajından yaratıldığını, böyle olmayan hayvanlara yönelik kaba olmadıktan sonra davranışımızın pek bir öneminin olmadığını belirtir. Hayvanlara karşı acımasızca davranmamamızın nedeni ise bu yolda insanlara da acımasızca davranmamaya alışacak olmamızdır. Yine Platon, Descartes gibi filozoflar da Tanrı, evren ve akıl ilişkisi üzerinden hareket ederler, akıl sahibi olmaları 
nedeniyle tanrı benzeri insanlardan farklı, böyle bir rasyonelliğe sahip olmayan hayvanların evreni anlayamayacakları, salt “şey"lere benzer oldukları kabul edilir. Costello'nun vurguladığı gibi Kant bile bu konuda iyi bir şekilde ilerlemez; açıklamalarında hayvanlara yönelik olumlu olabilecek kimi sezgileri başarılı bir şekilde takip etmez (Coetzee, 1999: 2223). ${ }^{1}$ Örneğin hayvanları nesneler gibi şeyler sınıfında ele alır, onları akılsal yapıcılar olan insanların amaçlar krallığından uzak tutar (Korsgaard, 2013: 629-631; Korsgaard, 2018: 98 114 birinci dipnot, ayrıca s. 113, 119). Oysa Kant'tan farklı olarak Costello'ya göre “akı1 evrenin var olanı değil aksine sadece insan beyninin bir var olanıdır.” (Coetzee, 1999: 23).

Costello'nun 70 yıllık deneyiminden öğrendiği şey, aklın evrenin ya da tanrının bir var olanı olmayıp salt insan düşüncenin spektrumu olduğudur, dolayısıyla kendisi eski filozofların görüşlerini süsleyerek abartmamamız gerektiğini düşünür (Coetzee, 1999: 23). Ona göre aklı, "evrenin gizlerine ulaşmaya izin veren bir yetinin gelişmesinden ziyade” bir satranç oyuncusunun satranç oynamasına benzer bir şey olarak alabilir, bu oyunu motive eden şeyleri evrenin merkezine yerleştirebiliriz (Coetzee, 1996: 25). Ayrıca Costello şu iki durumu da vurgular: Aklın varlığına bağlı olarak tanrıya yakınlığımızı ve uzaklığımızı tespit etmemiz kolay olmayacaktır (Coetzee, 1999: 24). İkinci olarak akla bu geçerliliği veren akıldır, ona yabancı olanlar için bu durum bir totolojiden başka bir şey değildir (Coetzee, 1999: 25).

Gelgelelim Costello'nun tarihsel bir olay olarak dikkat çektiği gibi zamanla savaşarak sessizliğe gömdüğümüz hayvanları akılsal temelde ele alarak onlara değer biçmeye başladık. ${ }^{2}$ Kendisi bu değer biçişi Kafka'nın maymununda, Bilim Akademisi'ne, bir grup toplanmış uzmana bir okuma yapmayı öneren Kırmızı Peter'inde görebileceğimizi belirtir. Çünkü Peter bu okumada "primat davranışının bir soruşturucu olarak değil konuşma becerisini sergileyen damgalanmış, işaretlenmiş, yaralı bir hayvan olarak" karşımıza çıkar. Costello konuştuğu bir grup uzmana bunu hatırlatır, Peter'in her kelimesine dokunan bu yarayı sergilemediğini belirtir. Peter aslında canavarların (beasts) sessizliğinden aklın gevezeliğine başkalarının cezasını çeken, bir günah keçisi olan biri gibi düşmüş durumdadır (Coetzee, 1999: 25-26).

\footnotetext{
${ }^{1}$ Gerçekten de aynı düşünceyi bugün Kantçı Christine M. Korsgaard da dile getirir (Korsgaard, 2018: 131-132). Ancak Korsgaard bu noktada Kant'ı revize eder, hayvanlara bu konuda pek bir şey söylememiş olan Kant'ın felsefesi ile bakar, Kant'ın terimleriyle hayvanları kendinde bir amaç olarak ele alabileceğimiz bir teori ortaya koymaya çalışır (bkz. Korsgaard, 2018).

${ }^{2}$ Costello'nun dikkat çektiği gibi hayvanları sessizliğe gömüp değersizleştireceğimiz tarihsel süreç, hayvanlara karşı milyonlarca yıldır devam eden savaş ve silahın icadı ile gerçekleşmiştir. Silahın icadı ile savaşı kazanan insan, kabilenin bir parçası olmayan hayvanlara bir savaş mahkumu gibi davranarak onları istediği gibi suistimal etmeye başlamıştır (Coetzee, 1999: 58-59). Hayvanlara yönelik birçok suiistimal dahilinde, Costello'nun bir felsefe profesörünün sorularına cevapları içerisinde dikkat çektiği şu nokta önemlidir: Hayvanlara karşı yaklaşımlar kültürel farklılıklar gösterse de çocukların hayvanlarla ilişkileri doğal olarak uyumlu olmuş, biz yetişkinler çocuklara hayvanları öldürmeyi ve hayvanların etlerini yemeyi öğretmişizdir (Coetzee, 1999: 60-61). Hayvanlara karşı, özellikle Batı kültürünün kibirli duruşu hayvan yaşamını endüstrileştirenlerin, hayvan etini ticarileştirenlerin öncülüğünde (Coetzee, 1999: 61) eşi benzeri görülmemiş bir noktaya ulaşmıştır. Kültür hayvanlarla olan ortaklığımızı yıkmak için her şeyi yapmaktadır.
} 
Bu açıklamadan sonra Costello Kafka'nın Peter'1yla ilgili ilginç bir spekülasyonda bulunur. Belirttiğine göre Kafka “Akademi İçin Bir Rapor”u 1917 Kasım’ında yayımlar. Bundan 5 yıl önce, yani 1912'de ise psikolog Wolfgang Köhler önderliğinde, Prusya Bilimler Akademisi Tenerife Adası'nda maymunların, özellik de şempanzelerin mental kapasitelerini görmek için bir üst kumuştur. Costello, Kafka'nın kütüphanesinde ve çalışmalarında Köhler'in 1917'de yayımladığı raporu okuyup okumadığını bilmediklerini söyler. Ancak Kafka'nın bu raporu zaman dilimine bakarsak okuduğunu düşünebileceğimizi ve bu rapor doğrultusunda kendi raporunu biçimlendirmiş olduğu spekülasyonunu yapabileceğimizi belirtir. $\mathrm{Bu}$ sözünü ettiği spekülasyonda üstteki maymunlar, maymun ticareti yapan bir grup avcı tarafindan yakalanmıştır. Peter de bu maymunlardan biridir ve efendisi Köhler'den de birçok şey öğrenmiştir. Bu deneylerden bildiğimiz Sultan da Peter'in ilk örneği durumundadır ve kendisi açlıktan dolayı muzu alması için yapılan birçok testi de geçmiştir (Coetzee, 1999: 27-28).

Costello’ya göre testlerde hep doğru olarak kabul edilen düşünce, birinin muzlara ulaşmak için kasaları nasıl kullanacağı, kasalardaki taşları nasıl boşaltacağı olmuştur. Yani kimse Sultan'ın bakış açısından şu soruların bir geçerliliği olacağını düşünmez: "Muzlar neden yukarıdadır?”, "Neden Köhler onu aç bırakıyor?”, “Neden artık onu sevmiyor?”, “Onunla sorunu nedir?”, “Onunla ilgili hangi yanlış kavrama sahip ki onun aşağıda duran bir muzu almasını sağlamak yerine bir sopayla asılı olan bir muza ulaşmasının daha kolay olacağını inanıyor?”, "Neden o sandıkları taşlarla dolduruyor?” (Coetzee, 1999: 28). Sultan bu soruları düşündükçe aç kalmaya mahkum görünür. Sultan bu gibi pratik ve araçsal aklın sınavına tabi tutulmakta, salt iştahını tatmin edecek bir organizma olarak karşımıza çıkmaktadır. Onun tarihi, örneğin avcıların annesini öldürdüğü, onun yakalanıp bir kafese hapsedilerek sadistik oyunların bir parçası olduğu, evrenin adaletine yönelik sorular sormak durumunda kaldığı unutulur (Coetzee, 1999: 29). "Kurgulanan psikolojik rejim, onu etik ve metafizikten uzak tutar..." (Coetzee, 1999: 29). Hapis içerisinde Sultan'ın en derin problemi, “evim nerede?”, "buraya nasıl geldim?” olarak görülmez, “deneyi yapanın tek-gayeli rejimi” Sultan'1 muz problemine odaklamaktır (Coetzee, 1999, s. 30). Yani hiçbir zaman hayvanların iyisine, zihin işleyişine dikkat edilmez, salt bizim iyimiz, en üstün bileşenimiz olarak gördüğümüz aklımıza dikkatle onlara gidilir. Oysa Korsgaard'ın vurguladığı gibi hayvanlardan daha zeki olmamı, entellektüel beceriler göstermemiz "daha yüksek bir ahlaki mevki”de yer aldığımızı göstermez (Korsgaard, 2018: 60).

İşte Costello etkileyici bir kurgu ile açtı̆̆ derslerine dair tespitlerini, ahlaki kibirliliğimize yönelik kimi uyarılarda bulunan şu sözleriyle sürdürür: 
Kafka'nın maymunundan uzak bir geriye doğru; onun papyonu, akşam yemeği ceketi, bir tutam ders notu ile Tenerife'deki bölme etrafinda uzanan tutsakların üzgün bir şekilde dizilişini tartalım. Peter ne kadar da uzağa seyahat etmiştir! Artık şunu sormaya hakkımız var: O [Peter] ulaştığı devasa entellektüel gelişimi karşıllğında, amfi görgüsü ve akademik retoriği karşılığında neleri bırakmak zorunda kalmıştır? Cevap nesil, ardışıklık/silsile de olmak üzere birçok şey. Eğer Kırmızı Peter herhangi bir duyuya (sense) sahip olsaydı, herhangi bir çocuğa sahip olamayacaktı. Çünkü Kafka'nın hikayesinde esir alanların onu eşleştirmeye çalıştırdıkları umutsuz, yarı-deli dişi maymundan dolayı sadece bir canavara (monster) baba olacaktı. Kırmızı Peter'ın çocuğunu imgeleme (imagine) güçlügü Kafka'nın kendisinin çocuğunu imgelemek kadar zordur. Melezler kısırdır ya da kısır olmalıdır; Kafka da hem kendisi hem de Kırmızı Peter'ı kısır olarak, acı çeken hayvan bedenleri üzerinde açıklanamaz bir şekilde tutturulmuş (mount) canavarsı düşünce aletleri olarak görmüştür. Kafka'nın hayatta kalan fotoğraflarında karşılaştığımız bakış, saf şaşkınlıkta bir bakıştır: şaşkın, hayret içinde, tehlike işaretli (alarmed). Tüm insanlar arasında Kafka insanlık içerisinde en emniyetsizdir (insecure). $\mathrm{O}$ şunu söyler görünür: $\mathrm{Bu}$ Tanrı'nın imajı mı? (Coetzee, 1999: 30-31).

$\mathrm{Bu}$ sözlerden sonra, oğlunun yanında oturan gelini Norma kocasına Costello'nun söylediği şeylerin derme çatma olduğunu, örgüsünü kaybettiğini belirtir. Bunları duymayan Costello konuşmasına zeki bulduğu ve itici olmadığını düşündüğü filozof Thomas Nagel'in "Bir Yarasa Olmak Neye Benzer" ("What is it like to be a bat") adında çok ses getiren makalesine yönelerek devam eder. Ona göre Nagel bu makalede bir yarasaya dair ilginç bir konuyu gündeme getirse de cevabı sınırlı olmuştur. Çünkü Nagel için bir yarasa olmanın neye benzediğini bilmek "bir yarasanın duyu kipleri yoluyla yarasa-yaşamını deneyimleyebilmeyi" gerektirir (Coetzee, 1999: 33). Oysa “yaşayan bir yarasa olmak tümüyle var olmaktır.” Bizler de dahil tüm hayvanların var olmaları yaşayan, bedene gömülü (embodied) bir ruha sahip olmalarıyla gerçekleşir. Descartes gibi filozoflarda rahatlıkla görebileceğimiz bir şekilde hayvanlarda da olan bu ruh düşünmeyle ilişskilendirilmediği için hayvanların var olmaları ve yaşamları bir makine yaşamı gibi görülmüştür (Coetzee, 1999: 33). Böylelikle, yani hayvanların yaşamdan gelen neşelerini/sevinçlerini (joy) bedenle ilişkilendirmeyip düşünceyle ele aldığımız için hayvanları hapsetme, öldürme, onların cesetlerine onursuzca davranma hakkını kendimizde bulabilmekteyiz (Coetzee, 1999: 34).

Costello'nun dikkat çektiği gibi Batı'nın kültür ve felsefesinde bir şekilde hakim olan bu rasyonalist, idealist çizgi içerisinde diğerlerinin varlığını görebileceğimiz yürekte (heart) konumlanan "sempati/duygudaşl1k" yetisine dikkat etmememiz neticesinde ne hayvanların ne 
de ölüm kamplarındaki insanların varlığına karşı sorumlu davranabildik. O dönemde birçok insan hayvan vagonlarında kamplara götürülen insanların yerinde olabileceklerini kendilerine sormadılar, bunun yerine ilgili kişilerin yakılacak kişiler olduğunu belirtebilmekle yetindiler. Hiçbirinin akıllarına yansaydım ne olurdu diye sormak gelmedi (Coetzee, 1999: 34). Dolayısıyla hepsi yürekleri kapalı bir şekilde davranabildi (Coetzee, 1999: 35).

Coetzee ise bu kapalılık, sempati yoksunluğu karşısında yüreğin sınırsızca açıklığına, yani sempatinin, sempatik imgelemin aslında sınırsızca genişleyebileceğine inanır. Kendisi yazdığı romanların karakterlerinde bunu deneyimler, örneğin hiç var olmamış bir karakterin varlığını varoluşa getirebilmiş, bu karakteri başarılı bir şekilde karakterize edebilmiştir. $\mathrm{Bu}$ duruma dikkatle Coetzee "kendisiyle yaşamın altyapısını paylaşan herhangi bir varolanın, bir yarasanın ya da bir şempanzenin ya da bir midyenin varoluşa ilerleyişini düşünebilirim" (Coetzee, 1999: 35) der ve şunu ekler:

Son bir defa etrafımızda tüm ölüm yerlerine, büyük bir kommünal çaba ile yüreklerimizi kapadığımız kesim yerlerine dönüyorum. Her gün yeni bir holocoust. Gelgelelim görebildiğim kadarıyla ahlaki varlığımız bu durumdan etkilenmemiş görünüyor. Kendimizi lekelenmiş/kusurlu hissetmiyoruz. Bu durum bana, her şeyi yapabilsek de kendimizi temize çıkarabileceğimizi düşündürtüyor (Coetzee, 1999: 35).

Costello'nun ilk dersi için ortaya koymaya çalıştığı bu değerlendirmelerinde temel olarak şunlara dikkat çekmeye çalıştığını söyleyebiliriz: Tarihsel olarak hayvanlara karşı kazandığımız savaş sonunda, onları rasyonalite temelinde değersiz görmeye başladık. Rasyonaliteyi tanrıya yakın olmak şeklindeki açıklamalarla kutsallaştırdık, yüceleştirdik ve hayvanları, hayvansal varoluşumuzu küçümsedik. Maymun deneylerinde vurgulandığı üzere hayvanların iyisini, belli bir doğa ve topluluk içerisinde "mutlu" bir yaşam sürmekte olduklarını görmemeye başladık; onları ve yaşadıkları toprakları istediğimiz gibi kullandık, zapt ettik. Kafka'nın maymunundan akademisyenlerin talep ettiği şu beklenti içerisinde olduk: Onlar bizler gibi düşünebildikleri, iletişim kurabildikleri, akıl yürütebildikleri ölçüde bir değere sahiptirler. Akla dayanan bu beklenti içerisinde, bizler gibi olmayan hayvanların canlılığını, yaşadıklarını, acı çektiklerini acımasızca görmezden gelerek onlara istediğimizi yapabildik. Ve bu vicdani körlük, sempatiden yoksunluk, duyarsızlık bir şekilde Yahudilerin hayvanlar gibi öldürülmesinde de kendini göstermiştir.

Evet Costello ilk dersini bu mesajlarla bitirir. Ancak oturum sonlanmadan önce gelini Norma soru sormak için kendini tutamaz ve kocasının uyarılarına rağmen soru sormasının hakkı olduğunu söyleyerek elini kaldırır. Oturumu yöneten fakülte dekan ise cuma günkü oturumda tartışmanın daha ayrıntılı olacağını belirleterek soru almak istemese de Costello 
kibarca bir iki soru alabileceğini söyler. Dekan sözü öncelikle gelinin hemen arkasında oturan bir erkek dinleyiciye verir. Bu dinleyici Costello'nun, hayvan üretim çiftliklerinin kapatılmasını mı önerdiğini, et yemeyi bırakmamızı, hayvanlara daha insani davranmamızı mı istediğini, yoksa onlar üzerinde deneyler yapmayı bırakmamızı mı talep ettiğini bilmek ister (Coetzee, 1999: 36). Bu soru karşısında Costello amacının ilkeler, yasalar ortaya koymak olmadığını, temel ilgisinin daha kökensel olduğunu, ilgili düşüncelerin arkasında yatan şey üzerinde durduğunu söyler. İlke olarak önerebileceği tek şey ise olsa olsa "yüreğini açıp onun söylediği şeyi dinlemektir" (Coetzee, 1999: 37).

Bu cevaptan sonra dekan Norma'ya söz vermeden oturumu bitirir. Artık Costello için verilecek akşam yemeğine geçilecektir. Üniversite yemek listesine Costello'nun oğlunu ve gelinini de ekler. Daha önce vurguladığımız gibi bu süre zarfina kadar kimse Costello'nun oğlunun üniversitede çalıştığını bilmez. Gelgelelim yemeğe katılacak olan oğlu ise bekleyeceğimiz bir şekilde mutlu olmak bir yana huzursuzluk içerisindedir. Annesini gördüğü ve annesinin de torunlarını gördüğ̈ için mutlu olduğunu söylese de bu ziyaretin kendisini kötü gösterebileceğini düşündükçe annesiyle ilgili "keşke gelmeseydi” diye aklından geçirmeyi sürdürür. Annesinin sıradan yaşlı bir kadın gibi yaşamadığına üzülür ve hayvanlara yüreğini açacaksa bunu evde kalarak yapması gerektiğine inanır (Coetzee, 1999: 38). Akşam yemeğinde annesine vejetaryen olmasına yol açan şey sorulduğunda vereceği cevabı nasıl toparlayacağını, annesinin zararını nasıl iyileştireceğini hesap eder (Coetzee, 1999: 38). ${ }^{3}$ Kendisi bir anlamda daha önce gurur duyduğunu söylediği annesiyle pek de gurur duymamakta, aslında ondan utanmaktadir.

John belki bugün birçoğumuzun hastalığı olan bir davranışla, alışılmış toplumsal duyguların konforuna bağlı olarak annesinin yaşamını, anlamlı olan ve sorumluluk içeren seçimlerini kolaylıkla radikal kılabilmektedir. Açıkçası Costello'nun oğlunun durumu bize şunu deneyimletir: Toplumsal belirlenmişlikler böylesine radikal olmayan bir durumda bile en sevdiğimiz insanlara karşı, özellikle dünyaya ve kendine karşı ciddi bir farkındalık ile davrananlara, başka var olanlara karşı saygı ve özenle hareket edenlere karşı ne denli yıkıcı davranabileceğimizi göstermektedir. Toplumsal konfor paketleri içerisinde çoğunluk değerleri peşinde sürüklenerek başkalarına karşı kızgınlık ve nefret beslemenin nedenleri üzerinde durmak, kültürün ve geleneğin hastalıklı olabilecek yönleri karşısında dikkatli olmamızı

\footnotetext{
${ }^{3}$ Oğlunun belirttiğine göre annesi eşiyle "Plutarch Tepkisi” adını verdikleri, diyaloğu kapatan bir cevap ortaya koyar. Oğlu annesinin vejetaryen olmakla ilgili şu cevabı vereceğine inanır: "Neden et yemeyi reddettiğimi bana soruyorsan, kendi adıma ağzına ölü bir hayvanın cesedini koymuş olmana şaşırıyorum, kıyılmış eti çiğnemeyi, ölü-yaralı suları yutmayı tiksindirici (nasty) bulmamana şaşırıyorum." (Coetzee, 1999: 38).
} 
sağlayacaktır. Bunu yapmadığımız takdirde bilgece, adil işlemeyen geleneğin eşitsizlikleri ve kötülükleri karşısında mücadele etmemiz pek de mümkün olmayacaktır. ${ }^{4}$

Coetzee'nin Costello'nun oğlu üzerinden bahsettiğimiz bu geleneğin çarpıklığına dikkat çekmeye çalıştığını söyleyebiliriz. Bu denli bireysel ve özenli bir yaşam bile birinin çocuğu tarafından çekilmez görülebilmektedir. Aslında Costello bu farklılığı ile biraz da "farklı görme" biçimleri üzerinde durduğundan oğlu için zorluk çıkarmaktadır. Örneğin bu farklı görme biçimini, yemekte şempanzeler üzerine bir deneyi anlattığı Ruth Orkin adındaki psikologla olan diyaloğunda fark edebiliriz. Psikolog Costello'ya şempanzeden kendi fotoğrafını belli fotoğraf yığınlarına koymasını istedikleri zaman, şempanzenin fotoğrafını diğer maymun fotoğraflarının değil insanların yanına koyduğunu belirtir. Psikolog Orkin bu durum bağlamında şempanzenin onlardan biri olmayı istediğini düşünür. Costello ise katılıyorum der ama fotoğrafını oraya koymayı seçmesinin nedenini şuna yorar: Onlar bu seçimle kilitli kalan maymunlar yerine özgür olan insanlar gibi özgür olmayı istiyor olabilirler. Yemekte diyaloglar bu şekilde ilerler, diyaloglarda Costello'nun değindiği önemli bir diğer nokta ise hayvanlarla farklılığımız temelinde (Coetzee, 1999: 41) hareket etmemiz, örneğin bilince (conciousness) sahip olmadıklarını kabul ederek onları kendi amaçlarımız için istediğimiz gibi kullanmakta ve öldürmekte sorun görmeden davranmamızdır (Coetzee, 1999: 44). Aslında Wunderlich adındaki konuklardan birinin haklı bir şekilde belirttiği gibi, hayvanların bir bilince sahip olup olmamaları sisli, belirsiz bir konudur. Aynı konuk şuna da dikkat çeker: Bizler kendi türümüzü korumak için öz-bilinç becerisi taşımayan bebeklere bir buzağı gibi yaklaşmasak da buzağı öldürme konusunda bir sorun görmeyiz. Costello, bu kişiye ne diyeceğini bilemez ve sadece şunu ekler:

Sıklıkla düşünmenin (thinking) ne olduğunu, anlamanın (understanding) ne olduğunu merak ederim. Acaba evreni gerçekten hayvanlardan daha mı iyi anlıyoruz? Bir şeyi anlamak sıklıkla bana Rubik küplerinden biriyle oynamak gibi gelir. Tüm ufak yüzleri yerine getirdiğin zaman, vay canına, anlayıverirsin. Bir Rubik küpün içerisinde yaşıyorsan bu anlamlı gelir, aksi takdirde ise gelmez (Coetzee, 1999: 45).

Costello'nın bu metaforik açıklamasıyla insanın ve hayvanın düşünme ve anlamasındaki ortaklığa dikkat ettiğini, insanı hayvanlar karşısında daha üstün görmediğini söyleyebiliriz. Anlama, çok farklı yüzler içerisinde bir bilmeceler parçası olan yaşamda biraz da sorun çözebilme becerisidir. Açıkçası bunu bir şekilde hayvanlar da yapar. Gelgelelim insanlar akı1 gibi farklılıklara yaptıkları vurgularla bunu görmemeyi, diğer hayvanların bakış açısının değerini küçümsemeyi sürdürürler. İnsanlar bu küçümseyici bakış açısıyla da

\footnotetext{
${ }^{4}$ Bu konuda etkileyici bir okuma için (bkz. Nussbaum, 2013).
} 
kendilerini hayvanlara karşı ahlaki bir yükümlülük altına sokmazlar. Birçok filozof da akla verdikleri aşırı değer nedeniyle bu krizi tetiklemiş görünmektedir. ${ }^{5}$ İnsanların farklılığını aşırı yücelten açıklamalarla dünyada bir arada yaşadığımız diğer tüm canlıların, hayvanların araçsal, ikincil değerde ele alınmasına katkı sağlamışlardır. Yıkıcı etkilerini her geçen gün deneyimlediğimiz bu sorunlu durum içerisinde Costello, yine güzel bir kurguyla ilerleyen "Poets and Animals" adı altında diğer bir dersle kimi önemli noktalara dikkat çekmeye çalışır. Artık diğer derse geçebiliriz.

\section{3. ŞAİRLER VE HAYVANLAR}

Costello derse başlamadan önce, yine Norma ve kocası arasında geçen bir diyalogla karşılaşırız. Norma kocasına derse gidip gitmeyeceğini ve dersin konusunun ne olduğunu sorar. Kocası bu soru üzerine gitmek zorunda olduğunu, dersin başlığının "Poets and Animals" olduğunu ve pek fazla kişinin geleceğini düşünmediğini söyler. Norma Costello'nun bu sefer felsefe değil de bildiği bir konuda konuşacağı için çok mutlu olduğunu belirtir. Annesine karşı karısının ironisini fark eden John, karısına aklında olanın ne olduğunu sorar. $\mathrm{Bu}$ durumda zihin felsefecisi Norma konuyu biraz daha açmaya çalışır, kayınvalidesinin aklın doğası üzerine olan tespitlerini gündeme getirir. Norma’ya göre Costello için "rasyonel açıklamalar salt insan zihninin yapısının bir sonucudur ki hayvanlar da kendi zihinlerinin yapılarına göre kendi açıklamalarına sahiptirler ve onlarla bir dili paylaşamadığımız için de bu yapıya ulaşamayız." (Costello, 1999: 47). John burada sorunun ne olduğunu anlayamaz, annesine hak verir bir şekilde davranır. Norma bunun üzerine devam eder, bir fizikçi olan kocasının annesi Costello'nun açıklamaların çok naif olduğunu bilmesi gerektiğini söyler. Çünkü bu açıklamalar herkesin, ineğin, sincabın v.s. dünya görüşüne saygıyı gündeme getirerek, saygıya çok fazla zaman ayırmamıza yol açarak düşünmeye yer bırakmaz, entellektüel bir felce sebep olur. Norma şunu da ekler: Bir sincap elbette bir dünya görüşüne, bakış açısına sahiptir; hayatta kalmak için palamutları, ağaçları, iklimi, köpekleri, otomobilleri, karşı cinsi gözetir, ama hepsi bu. Onların zihinlerine dair başka sonuçlara ulaşamayız, zihinleri çok basit bir mekanizma ile işler. Descartes'ın haklı olarak vurguladığı gibi "sadece biyolojik bir otomat"tırlar (Coetzee, 1999: 48). "Soyut bir şekilde, bir hayvan zihni ile bir hayvan zihnini taklit eden bir makineyi ayıramazsın.” (Coetzee, 1999: 48).

Bu açıklamalar üzerine John, "İnsanlar farklı mı?” diye sorar. Bu sorudan iyice rahatsız olan Norma açıklamalarını sürdürür. Ona göre insanlar matematiği keşfetmiş, teleskoplar, hesap

\footnotetext{
${ }^{5} \mathrm{Bu}$ durumu Aristoteles'ten başlatan ve Batı felsefesinin bir krizi olarak nitelendiren Sorabji'nin tarihsel okuması için (bkz. Sorabji, 1993).
} 
makineleri yapmışlardır. Yani rasyonalizm annesinin de dikkat çektiği gibi bir oyun değil "gerçek dünyanın gerçek bilgisini” veren bir yetidir (Coetzee, 1999: 48). John ise bunun üzerine şunu sorar: 'Katılıyorum. Ama düşünmenin ve Mars'a insansız uzay mekiği yollamanın bir sincabın düşünmesine ve dışarı firlayıp bir findığı yemesine çok benzer olduğu bir durumdan başka bir pozisyon yok mu? Belki de onun [annesi Costello’nun] kastettiği şey buydu?” (Coetzee, 1999: 48). Norma, akıl ve yargılamayla ilgili böyle bir pozisyonun olamayacağını olsa olsa Fransız irrasyonalistler gibi bunun akıldan geri çekilen birinin pozisyonu olacağını belirtir. Bunun üzerine John karısına şaşırdığını, onun eski moda rasyonalistler gibi konuştuğunu söyler (Coetzee, 1999: 48-49). Konuşma bir şekilde biter ve John annesini dersin olduğu yere götürür ve sonrasında hemen geri dönmek üzere bir toplantıya gider.

Artık Costello'nun dersi başlar. Costello dersini hayvanların insan nitelikleriyle simgelendiklerini; örneğin aslanın cesaret, baykuşun ise bilgelik ile temsil edildiklerini belirterek konuyu açar. Daha sonra dinleyicilere de dağıtılan şair Rilke’nin "Panter” ve şair Ted Hughes'in "Jaguar" ve "Second Glance at a Jaguar" şiirleriyle devam eder. Costello bu şiirlerde Rilke'nin panterin fiziğinden gelen enerjisine, temel fiziksel imajına dikkat çekmeye çalıştığını söyler. Rilke'ye bir nazire yazan Hughes ise şiirinin kurgusunu hayvanat bahçesinde olan bir Jaguar ile işler. Jaguarın üşüşen bir kalabalıkta "hipnotize olmuş", "korkmuş", “dehşete kapılmış", “altüst olmuş duruşunu”, "sınırlarının ötesinde zorlanan anlama gücünü” göstermeye çalışır (Costello, 1999: 50-51). Costello’ya göre bu şiirde,

Jaguarın vizyonu panterden farklı olarak körleşmiş değildir. Aksine gözleri uzamın karanlığını deler. Kafesin onun için hiçbir realitesi yoktur, başka bir yerdedir. Zihni soyut olmaktan ziyade kinetik olduğu için başka bir yerdedir: Kaslarının tepkisi doğası gereği Newton'un üç boyutlu kutusundan (box) farklı olarak oldukça farklı bir uzam vasıtasıylabizzat kendisine dönen dairevi bir uzam ile onu hareket ettirir. Böylece Hughes, büyük hayvanları kafese koyma etiğini bir kenara koyarak, dünya-içinde-olmanın (being-in-theworld) farklı bir türüne doğru yol alışını hisseder; bu his, kafesin önündeki deneyim rüyadeneyimine, kolektif bilinçsizlikle ele alınan deneyime ait göründüğü için tümüyle bize yabancı olmayan bir histir. Bu şiirlerde Jaguarı göründüğü şekilde değil hareket ettiği şekilde görürüz. Beden, bedenin hareket ettiği gibidir ya da yaşamın mevcut akışı onda hareket etmektedir. Şiirler bu hareket ediş şeklini imgelememizi, bu bedende ikamet etmemizi ister. Hughes ile birlikte sorun olan şey-vurguladığım şekliyle-diğer zihinde değil diğer bedende ikamet etmektir (Coetzee, 1999: 51).

Costello bu açıklamalarında şuna dikkat çekmeye çalışır: Hughes'un şiiri, poetik keşif vasıtasıyla, yaşayan bir bedeni pek de açıklayamayacağımız bir şekilde kendimizde var 
k1labileceğimizi gösterir. O yani Jaguar poetik güçle bizledir, bizde dalgalanarak bedenimize egemen olur. Costello için bu deneyim şamanist, tinsel bir sahiplenme, arketip bir psikoloji karışımı primitif bir tür deneyimdir. Hughes bizde böyle bir deneyimi yaşatmak için, belli bir tikel Jaguar ile bizi yüz yüze getirir; çünkü soyut bir jaguarın deneyiminin, soyutlamaların, Platonik yaklaşımların bizi harekete geçiremeyeceğini görür. Şiirin dizelerinde tikel Jaguarda gömülü olan tümel Jaguar Platonik olarak kalmaya devam etse de dizeler her bir parçanın çoklu rollerini görmemizi sağlar. Şiir bizi, her yaşayan yaratıktaki bu dinamizme, bütünlüğe ulaştırır, Jaguar'ın kendi bireysel yaşamı için savaşırken bir Jaguar ideasından daha aşağıda olduğunu düşündürmez.

Costello'nun dikkat çektiği gibi bu durumu Jaguar değil sadece insan idrak eder. Diğer dans edenler, yani diğer yaratıklar dansı anlamazlarken insan bu dansı anlar ve entellektüel bir varlık olarak karşımıza çıkar. Jaguar'ın tikel varoluşunu aşıp Jaguar tümelliği gibi tümellikler içerisinde farklılığını görür. $\mathrm{Bu}$ farklılı̆̆ı ile, yani tümele ulaşan anlayış, idrak ve entellektüellik ile de ne kadar alabalığı avlayacağına, ne kadar Jaguara tuzak kuracağına karar vermeye başlar (Coetzee, 1999: 53-54). Dolayısıyla Costello daha önce de üzerinde durduğumuz şu konuda haklı görünür: Akıl ve konuşma (speech) bizlerin Homo ve diğer primatlar arasındaki ayrımı gerekçelendirmemize ve bu gerekçeyle de hayvanları kolaylıkla istismar etmemize sebep olmaktadır (Coetzee, 1999: 55). Richard Sorabji'nin ifadesi ile söylersek, diğer hayvanlarla kriz aklın bu gücüne yapılan ayırt edici tespitlerle başlamıştır. Batı felsefe literatüründe insanın hayvandan ayrıldığı noktaları tespit etmeye çalışan çok büyük bir literatür olduğu görülmektedir (bkz. Sorabji, 1993).

Şimdi tüm bu literatür içerisinde belki de en kilit nokta Costello’ya soru soran bir felsefe profesörünün dikkat çektiği gibi, Batı kültürel kibri içerisinde hayvanların çok sınırlı iletişim becerilerine sahip olduklarının kabul edilmesidir. Bu iletişim sınırlılığı nedeniyle hayvan haklarını bile hayvanlar değil insanlar hayata geçirmiştir (Coetzee, 1999: 61-62). Costello ise bu anlayışın, yani hayvanların ahmak olduğu düşüncesinin "insan merkezli” (anthropocentric) olduğuna inanır. Onun örneğiyle söylersek Borneo ormanlarına bırakılan bir insan belki de bir hafta içerisinde açlıktan ölecektir. Gerçeklik karşısında hayvanların davranışlarını ölçmek için tasarlanan soyut deneyler süreci ahmakça bir şekilde yaşamın kompleksliğinden uzaktır (Coetzee, 1999: 62-63). ${ }^{6}$

\footnotetext{
${ }^{6}$ Stephan Mulhall'ın Coetzee üzerine yazdığı The Wounded Animal (2009) eserinde Derek Parfit, Jeff McMahan'ın [ve aslında Anglosakson birçok filozofun] insanı bu şekilde kimi düşünce deneylerine dayalı metafizik varsayımlarla almalarına dikkat çekmesi anlamlıdır. Bu filozoflar düşünce deneyleri olarak ele aldıkları kimi örnekler ve olaylarla insanın doğasını, kişiliğini, benliğini/kendiliğini (self) tespit edip insanın ahlaki, etik yaşamını bu metafiziksel tartışma zemininde değerlendirirler. Bir anlamda bu deneyler değerlendirmelerinde bir standart, ölçüt verir (Mulhall, 2009: 24-35). Oysa Mulhall'ın dikkat çektiği gibi insanın kişiliği böyle bir kurgusal metafiziksellikte alınamaz, "kişilik kişilerarası etiğin metafizik temeli değil, bizzat etik bir nosyondur.” (Mulhall 2009: 30). Bizler yukarıdaki deneyler tarzında Maymuna sokulduğumuz için, McMahan'ın kişiliği etik görmemesi gibi, maymunu metafizik bir soyut testin parçası yapar ve bu yolla
} 
Ayrıca Costello'nun Camus deneyimi üzerinden dikkat çektiği gibi hayvanların konuşamadığı da doğru değildir. Kendisini dinleyelim:

Albert Camus Cezayir'de genç bir çocukken babaannesi arka bahçedeki kafesten tavuklardan birini getirmesini söylemiştir. Kendisi talimata uymuş, sonrasında ise mutfak bıçağıyla, kanı yeri kirletmemesi için bir kaseye tutturulmuş olan tavuğun başının kesilişini izlemiştir.

Bu tavuğun ölüm-çığlığı çocuğun hafizasında öylesine iz bırakmışır ki 1958'de giyotin ile öldürmeye karşı ateşli bir saldırı kaleme almasına yol açmıştır. Bu polemik de kısmi olarak Fransa'da idam cezasının kaldırılmasını sağlamıştır. $O$ halde tavuğun konuşmadığını kim söyleyebilir? (Coetzee, 1999: 63).

Sözünü ettiğimiz felsefe profesörü Costello'nun cevaplamasını istediği iki konuyu daha gündeme getirir: Birincisi yaşamın hayvanlara bizler kadar önemli gelmemesidir, içgüdüsel olarak yaşamak için bizler gibi savaşsalar bile ölümü 'anlayamazlar', ölüm korkusu karşısında bizler gibi sarsılmazlar. Onlar için ölüm ruhta değil organizmada olan bir şeydir, sadece yaşarlar ve ölürler. Dolayısıyla bir tavuğu öldüren kasap ile bir insanı öldüren infazcıyı aynı göremeyiz, onları öldürmek, gaddarca olmadıktan sonra, insanı öldürmekten farklı olarak meşru bir durumdur (Coetzee, 1999: 63-64). ${ }^{7}$ İkinci konu ise hayvanlar ve insanlar arasında Thomas Aquinas'ın işaret etmiş olduğu şekilde ortaklığımızın çok az olmasından ötürü onlarla bir dostluk kuramayacak olmamızdır (Coetzee, 1999: 65). Costello felsefe profesörünün bu düşüncelerine karşı şiirle gündeme getirdiği hayvanın varlığının bütünlüğüne dikkat çekerek cevap vermeye çalışır. Costello'ya göre hayvanın korku karşısında entellektüel, imgelemsel bir korku yaşamıyor olması onun yaşayan bir beden olarak tüm varlığıyla bu korkuyu yaşadığını unutturmamalıdır. Hayvanların bütünlüklü, soyut olmayan, entellektüel olmayan doğalarının ölümle ilişkisini entellektüalist, dar bir çerçevede ele alamayız (Coetzee, 1999: 65). Salt böyle bir perspektifle ölüme yaklaşarak yaşamın hayvanlar için insanlar kadar önemli olmayacağını söylemek çok yetersizdir. Costello bu tarzda düşünen bir filozofa şuna hatırlatma ihtiyacı duyar: süt içen bir buzağı anneyle belli bir anlamlı ilişkiye ve annesinin yokluğunun değerine dair yeterli, belli bir anlayışa sahiptir (Coetzee, 1999: 6566). Costello bizi bir süt buzağısından ayıran şeyin akıl temelinde ele alınmasından rahatsızlık

da onun yaşamının belli “iyi”si, "iyiler”i olduğunu unuturuz, yani maymunun doğasını yaşamının bütünselliği içerisinde değil salt bir tür soyut metafiziksel deneylerle, testlerle ele alırız. Onun ne denli zeki olabileceğine ne denli toplumsal, politik beceriler gösterebileceğine, diğer üyelerine ne denli bağlı olabileceğine dikkat etmeyiz (hayvanların bu üstünlükleri, erdemleri için bkz. MacIntyre, 2002; Nussbaum, 2003).

${ }^{7}$ Burada tartışmasına giremeyeceğimiz hayvanların ve insanların ölüm deneyimiyle ilgili farklılıklarına dikkat ederek ilerleyen değerlendirmeler için (bkz. McMahan, 2002; Korsgaard, 2018). 
duyar ve akla dikkatle tartışmada ortak bir zemin bulmayı reddeder. Belli aklı paylaşan kişilerle salt bu temelde, uzun bir felsefe geleneğinde karşılaştığımız bir anlayış içerisinde bu sorunun, hayvanlara yönelik bir felsefe tartışmasını yürütmenin zor olacağını görür. Bizi şiirler üzerinden dikkat çekmeye çalıştığı o entellektüel olmayan doğaya çekmeye çalışır ve dersini burada bitirir.

Costello bu etkileyici ders sonrasında son akşamını yine oğlunun evinde geçirir. Ertesi sabah oğlu John annesini havaalanına bırakacaktır. Norma ise ayrılığın, vedanın yaklaştığı bu son gecede bile sinirli bir haldedir. Kayınvalidesinin açıklamalarını, tarzını bir "yiyecekdüşkünlüğ̈̈” (food-faddism) olarak görür, annesi geldiğinde insanların, özellikle çocukların yiyecek alışkanlıklarını değiştirecek olması isteğine hala kızgınlık duyar. Kamusal derslerle tüm topluluğa yayacağını düşündüğü bu isteğin bir iktidar uygulamak olduğunu düşünür. Oğlu ise bu noktada artık dayanamaz ve eşine itiraz eder, annesinin görüşlerin çok içten olduğunu ve annesini "kendi tercihlerini birine dayatmaya çalışmak yerine bir hatip, bir sosyal reformcu olarak görmeye çalışması” gerektiğini söyler. Sonuçta kendisinin vurguladığı gibi "annesinin et yemekten tiksinmesi ile kendisinin salyangoz ve çekirge yemekten tiksinmesi arasında” pek de bir fark yoktur. Bu sözler karşısında mırıldanan Norma ise eşine onun bu konuda kamusal adımlar atmadığını, "özel olan”ı "kamusal bir tabu" haline getirmediğini belirtir (Coetzee, 1999: 67) ve aralarında şu diyalog geçer:

“Onu bir hatip olarak görmeye hoş geldin. Ancak diğer hatiplere ve onların insanlığı kurtarılmış ve lanetli (damned) olarak ayırdıkları şemaya bir bak. Annene sahip çıkmak istediğin birlik böyle bir şey mi? Elizabeth Costello ve onun, o Cesur Yeni Dünyası'na doldurarak kurtarmak istediği, İkinci Nuh’un Gemisi (Second Ark); köpekleri, kedileri ve kurtlarıyla birlikte et yeme günahından dolayı hiçbir zaman suçlu değil, sıtma virüsü, kuduz virüsü, HIV virüsü ile söyleyecek bir şeyi yok.”

"Norma abartiyorsun."

“Abartmıyorum, eğer annen çocuklara zavallı küçük buzağılar ve kötü insanların onlara neler yaptıklarını anlatarak arkamdan kuyumu kazmaya çalışmasaydı ona daha fazla saygım olurdu. Anne bu tavuk ya da tuna-balığı dana yavrusu mu? diye soran çocuklara yemek yedirmeye çalışmaktan yoruluyorum. Bu bir iktidar oyunundan başka bir şey değil, Onun büyük kahramanı Franz Kafka da ailesi ile aynı oyunu oynadı. Bunu, şunu yemeyi reddettiğini, aç kalmayı tercih ettiğini söyledi. Böylece onun önünde yemek yiyen herkes kendini suçlu hissederken o erdemli hissederek oturabildi. Bu hasta bir oyun, çocukların bana karşı bu oyunu oynamalarına izin vermeyeceğim."

"Birkaç saat sonra gidecek, artık normale dönelim." 
“İyi ona benim için güle güle dersin. Erken kalkmayacağım.” (Coetzee, 1999: 68).

Oğlu böyle bir diyalogun ertesi sabahı annesini havaalanına götürürken Norma için özür diler, çok fazla baskı altında olduğunu belirtir. Costello ise ne diyeceğini bilemez, kelimelerin zalimce olduğunu, kelimelerle yapılacak en iyi şeyin sadece bir yastıktan, yerdeki bir delikten bahsetmek olduğunu ekler. Kendisi bu dünyadaki yalnızlığını hissettirecek bir şekilde "artık nerede olduğunu bilemediğini” söyler, insanlar arasında normal ilişkiler kurmaya çalışsa da her yerde, her gün insanların "para için getirdiği ceset parçaları" gördügünü vurgular. Kimi nesneleri farklı hayal eder; örneğin dostlarının evinde beğendiği bir lambanın Polonyalı-Yahudi teninden yapıldığının söylendiğini, banyodaki bir sabunun yüzde yüz insan yağından (stearate) yapıldığını söylendiğini düşünür. Evet Costello rüya içerisinde değildir; bizzat bunları deneyimler. Kendisi bu acı verici yaşam deneyimleri ile oğlunun, Norma'nın ve torunlarının gözlerine baktığında “sevecenlik, insani bir sevecenlik" görür (Coetzee, 1999: 69). İşte bu halde iken kendine şunu söyler: "Sakin ol...pireyi deve yapıyorsun. Yaşam böyle. Başka herkes böyle bir yaşamla uzlaşıyor. Sen neden yapmiyorsun ki? Neden yapmıyorsun?” (Coetzee, 1999: 69). Oğlu John gözü yaşlı bir şekilde kendisine dönen annesinin bu soruya cevap isteyip istemediğini düşünür ve sonrasında arabasını kenara çeker, motoru durdurur ve annesini kolları arasına alır, annesinin soğuk kremini ve yaşlı teninin (flesh) kokusunu alarak kulağına şunu fisıldar: "Üzme kendini. Kısa bir süre içerisinde geçecek." (Coetzee, 1999: 69).

İşte bizler kirli kelimelerimiz içerisinde Kafka ve Costello gibilerin samimi, güçlü ve acı verici deneyimlerini belli bir sessizlikle anlamak yerine, onlara kalbimizi açacağımız tikel deneyimlere dikkat etmek yerine "aşırı entellektüellik", "aşırı insanilik" ve "toplumsal önyargılar" ile her türlü canlılığa gözlerimizi, kalbimizi kapayabiliriz. Bu kapalılıkla da Kafka gibi insanların Samsa'ya dönüşerek yaşamasına yol açar, Costello gibi insanları ailesine yabancılaştırarak yaşamasına sebep olacak denli radikalleştiririz. Oysa bu deneyimlerde bir şiddet, toplumsal önyargı değil bireysel bir sorumluluk vardır. Bizler ise böyle sorumluluk alanlarına kör olduğumuz ve kendimizi kapattığımız için, sempati yoksunluğu ile hayvanları hapsedip öldürmek kadar insanları firınlarda yakma gücünü gösterebilmekte ve dünyanın dengesini de her geçen gün bozabilmekteyiz. 


\section{SONUÇ}

Coetzee'nin etkileyici şekilde biten bu derslerini olay örgüsünü koruyarak serimlemeye çalıştık. Eseri okurken hayvanlar üzerine yazılan ve okuduğumuz felsefi eserlerin değerlendirmelerinden kimi eklemeler yapmayı, Coetzee'nin eklektik ilerleyen argümanlarını daha bütünlüklü, sistemli ele alabileceğimizi düşündük. Ancak eseri daha dikkatli okuyup, daha duyarlı ele aldıkça ona müdahale etmenin haksızlık olabileceğini fark ettik. Çünkü Coetzee kurgusal olay örgüsü ile işlediği hayvanların yaşamını daha iyi deneyimlememizi, imgelememizi amaçlar. Bu sorunu felsefenin ağırlıklı olarak yaptığı gibi tümele, kavramlara dikkat eden rasyonel bilginin sınırları içerisinde ele almaz. Bu sınırlar yer yer aile, dostluk gibi bağları bile anlamamızın önüne geçebilmektedir. Bir anne ve edebiyatçı olarak Costello bu deneyimi bizzat yaşar. İşte Coetzee kurguladığı bu deneyim üzerinden bir annenin çocuğu ve zihin felsefesi doktorasına sahip gelini ile yaşadığı acılı deneyime, "poetik imgelem"in izin vereceği "sempati" ile ulaşmamızı ister. Bu poetik imgelemde görmemiz gereken şey Costello'nun ceset parçaları ile örülü bir yaşamda yaşarken her gün ölmekte olduğudur. Oğlu ve gelini ise acılar içerisindeki Costello'ya sempati ile sokulmaktan çok uzaktır. Oğlu ve gelini Norma'nın aklında olan tek şey “normal” gündelik yaşamlarında, “bürokratik” yaşamlarında “onaylanmak", "kabul görmek”tir. Örneğin gelini Norma anormal gördüğü Costello'nun yaşamının ve bu yaşamın iyilerinin çocuklarının yaşamına etki etmesini, kamusal yaşamın konforlu iyisine bulaşmasını istemez. John ise üç günlügüne ziyarete gelen annesiyle hasret gidermek yerine üniversitedeki insanların annesinden dolayı kendisiyle ilgili düşüneceği şeylerle meşguldür. $\mathrm{Bu}$ yaşamın tüketim ve iktidar gibi değerlerini benimsemiş görünen John ve Norma, Costello'ya yönelik yer yer kızgınlık yer yer de "utanç", "hoşnutsuzluk" duyarlar. Her ikisi de her şeyin metalaştığı kapital ilişkilerde bir hayvanın kendileri gibi “yaşama"sının, “canlı olma”sının değerini belki de birçoğumuz gibi unutmuş görünür, bunun utancını yaşamak yerine Costello’yu suçlarlar. İşte Coetzee "her şeyin metalaştığı", "katı olan her şeyin buharlaştığı" bir yaşamda Costello gibi olmanın zorluğunu, acısını hissettirmeye çalışır, Costello olmanın bedelini göstermek ister. Çünkü Nietzsche'nin ifadesi ile söylersek yaşamlarımızda "aşırı insanileşme"nin yıkıcı sonuçları bir oğlun annesinden bile uzaklaşmasına yol açmış görünür. Oysa bugün yaşadığımız küresel 1sınma gibi sorunlar hepimizin Costello gibilere saygı duymamız gerektiğini, utanılacak olanın bizler olduğunu açığa çıkarmaktadır. Dünyanın kurtuluşu, hayvanlar üzerine yazıp çizen birçok filozofun ve kimi çevrecilerin dikkat çektiği gibi, mümkün mertebe vejetaryen beslenme alışkanlıklarını benimsemekten geçmektedir. 


\section{KAYNAKÇA}

Coetzee, J. M. (1999). The Lives of Animals. Princeton: Princeton University Press.

Korsgaard, C.M. (2013). "Kantian Ethics, Animals, and the Law". Oxford Journal of Legal Studies 33 no. 4, s. 629-648.

Korsgaard, C. M. (2018). Fellow Creatures: Our Obligations to the Other Animals. Oxford: Oxford University Press.

MacIntyre, A. (2002). Dependent Rational Animals: Why Human Beings Need the Virtues. Chicago: Open Court.

McMahan, J. (2002). The Ethics of Killing: Problems at the Margins of Life. Oxford: Oxford University Press.

Mulhall, S. (2009). The Wounded Animal: J. M. Coetzee and The Difficulty of Reality in Literature and Philosophy. Princeton, Oxford: Princeton University Press.

Nussbaum, M. C. (2013). Political Emotions: Why Love Matters for Justice. Cambridge, Massachusetts: The Belknap Press of Harvard University Press.

Sorabji, R. (1993). Animal Minds and Human Morals: The Origins of the Western Debate. New York: Cornell University Press. 